\title{
Conservation in the first internal transcribed spacer region (ITS1) in Hematodinium species infecting crustacean hosts found in the UK and Newfoundland
}

\author{
H. J. Small ${ }^{1,2, *}$, J. D. Shields ${ }^{1}$, J. A. Moss ${ }^{1}$, K. S. Reece ${ }^{1}$ \\ ${ }^{1}$ Virginia Institute of Marine Science, College of William and Mary, Gloucester Point, Virginia 23062, USA \\ ${ }^{2}$ Present address: Centre for Environment, Fisheries \& Aquaculture Science (CEFAS), Weymouth Laboratory, Barrack Road, \\ The Nothe, Weymouth, Dorset DT4 8UB, UK
}

\begin{abstract}
Parasitic dinoflagellates in the genus Hematodinium infect a number of decapod crustaceans in waters off the UK, including the Norway lobster Nephrops norvegicus and the edible crab Cancer pagurus. This study investigated sequence variability in the first internal transcribed spacer (ITS1) region of the ribosomal RNA complex of Hematodinium spp. infecting N. norvegicus, C. pagurus, and Pagurus bernhardus from 4 locations in the UK and from the Hematodinium sp. infecting Chionoecetes opilio from the province of Newfoundland and Labrador, Canada. Phylogenetic analysis of the Hematodinium ITS1 sequences from $N$. norvegicus, $C$. pagurus, $P$. bernhardus and C. opilio suggest that these crustaceans are infected with the same species of Hematodinium. Length variability of the ITS1 region was observed (324 to $345 \mathrm{bp}$ ) and attributed to 4 variable microsatellite regions $(\mathrm{CATG})_{\mathrm{n}},(\mathrm{GCC})_{\mathrm{n}} \mathrm{TCCGC}(\mathrm{TG})_{\mathrm{n}},(\mathrm{TA})_{\mathrm{n}}$, and $(\mathrm{GAA})_{\mathrm{n}}(\mathrm{GGA})_{\mathrm{n}}$ within the sequenced ITS1 fragment. The observed variation may be due to co-infection of the host crustacean with several different strains of Hematodinium or differences among copies of ITS1 region within the genome of a single parasite cell. The Hematodinium ITS1 sequence from $N$. norvegicus, $C$. pagurus, $P$. bernhardus and $C$. opilio isolates was sufficiently conserved in primer binding regions targeted by previous molecular diagnostic assays; therefore, we suggest that this assay could be used to screen for Hematodinium infections in these crustacean hosts.
\end{abstract}

KEY WORDS: Hematodinium · Conservation of ITS1 $\cdot$ Crustacean hosts $\cdot$ Parasite Resale or republication not permitted without written consent of the publisher

\section{INTRODUCTION}

Several marine crustaceans are parasitized by dinoflagellates of the genus Hematodinium. The type species, Hematodinium perezi, was first found to infect the shore crab Carcinus maenas and the harbour crab Liocarcinus depurator and was described by Chatton \& Poisson (1931). It has since been tentatively recorded from the blue crab Callinectes sapidus (Newman \& Johnson 1975). A second species, H. australis, was described from the sand crab Portunus pelagicus by Hudson \& Shields (1994). Hematodinium-like dinoflagellates are found to infect many commercially impor- tant crustaceans (see Stentiford \& Shields 2005 for review) including the edible crab Cancer pagurus (Latrouite et al. 1988), the Norway lobster Nephrops norvegicus (Field et al. 1992), the velvet swimming crab Necora puber (Wilhelm \& Mialhe 1996), the tanner crab Chionoecetes bairdi (Meyers et al. 1987), the snow crab Chionoecetes opilio (Taylor \& Khan 1995) and recently the grooved tanner crab Chionoecetes tanneri (Bower et al. 2003). Hematodinium-like infections have caused significant annual economic losses to several national and international fisheries. These losses are due to morbidity (e.g. bitter crab disease) or mortality caused by Hematodinium spp. 
In waters surrounding the UK Hematodinium-like infections have been reported in Nephrops norvegicus from the Clyde and Irish seas (Field et al. 1992, 1998, Briggs \& McAliskey 2002) and in Cancer pagurus from the English Channel (Stentiford et al. 2002) and from the Atlantic Ocean (Anonymous 2004). Both N. norvegicus and C. pagurus support large and valuable fisheries in UK waters; however, it is unknown whether different species of Hematodinium parasites infect each of these different hosts or whether one species infects multiple hosts.

PCR-based diagnostics to detect Hematodinium spp. have been developed for detecting infections in several host species (Hudson \& Adlard 1994, Gruebl et al. 2002, Small et al. 2006, 2007). In the first 2 studies the primer binding regions were in the $18 \mathrm{~S}$ and $5.8 \mathrm{~S}$ ribosomal RNA genes and are almost certainly genus specific, not species specific, due to the conserved nature of these genes. Small et al. (2006) developed a potentially species-specific set of PCR primers to target the Hematodinium sp. infecting Nephrops norvegicus using the conserved 18S rRNA gene and variable first internal transcribed spacer region (ITS) of the rRNA gene complex. This PCR assay also detected infections in Cancer pagurus from the English Channel tentatively suggesting that this is either the same species or a closely related species to that infecting $N$. norvegicus.

The ribosomal RNA gene complex is present as tandemly repeated clusters of highly conserved genes encoding the 18S, 5.8S and 28S rRNA genes, which are separated by variable spacer sequences (Long \& Dawid 1980). Sequence variation in the ITS regions has been used to distinguish among species and strains of many other dinoflagellates and parasites, including Perkinsus marinus (Goggin 1994, Reece et al. 1997, Brown et al. 2004), Pfiesteria shumwayae (Litaker et al. 2003), trichomonad protozoans (Felleisen 1997), Entamoeba spp. (Som et al. 2000) and Hematodinium spp. (Hudson \& Adlard 1996). However, Small et al. (2006, 2007) observed that partial ITS1 region sequences from the Hematodinium spp. infecting Nephrops norvegicus and Callinectes sapidus were only 77 and
$82 \%$ similar, respectively, to the same sequences in Hudson \& Adlard's (1996) study, revealing an uncertainty over the sequence data and species hypothesis contained within that report.

In the current study DNA sequence variation of 16 Hematodinium spp. isolates from 5 geographically distinct areas, encompassing 4 host crustacean species (Table 1) was examined at the ITS1 rRNA locus to investigate similarities and differences among Hematodinium spp. infecting various hosts and assess the potential application of the PCR assay developed by Small et al. (2006) to detect infections in other crustaceans.

\section{MATERIALS AND METHODS}

Sample collection. Fourteen field isolates of Hematodinium spp. were obtained from 3 crustacean species. In addition, 2 in vitro culture samples of Hematodinium spp. were also obtained (see Table 1 for details). Infected haemolymph, hepatopancreas, gill tissue and cell culture samples were collected and preserved in $100 \%$ ethanol before DNA extraction. All isolates originated from crustaceans found in geographically separate locations surrounding the UK (Fig. 1), except for 2 samples of Hematodinium sp. from Chionoecetes opilio from Conception Bay, Newfoundland and Labrador, Canada.

DNA extraction and amplification. DNA was extracted from preserved tissues using a Qiagen DNeasy Tissue Kit following the manufacturer's protocol (Qiagen). The $3^{\prime}$ end of the $18 \mathrm{~S}$, complete ITS1 and the 5' end of the 5.8S rDNA genes were amplified using the forward primer (5'-GTT-CCC-CTT-GAA-GGA-GGAATT-C-3') and reverse primer (5'-CGC-ATT-TCGCTG-CGT-TCT-TC-3') previously described by Hudson \& Adlard (1994). The amplification conditions used were those described previously by Hudson \& Adlard (1994). Amplification products $(5 \mu \mathrm{l})$ were electrophoresed on a $1.5 \%(\mathrm{w} / \mathrm{v})$ agarose gel, stained with ethidium bromide and viewed under a UV light source.

Table 1. Hematodinium spp. Source and number of Hematodinium samples used in this study

\begin{tabular}{|lcccc|}
\hline Sample name & $\begin{array}{c}\text { No. of individuals } \\
\text { sampled }\end{array}$ & Host species & Sample location & rRNA GenBank sequences \\
\hline Nn1-3 & 3 & Nephrops norvegicus & Clyde Sea, UK & EF031966-EF031974 \\
Nn4-6 & 3 & Nephrops norvegicus & Irish Sea, UK & EF031975-EF031983 \\
Cp1-3 & 3 & Cancer pagurus & English channel, UK & EF031984-EF031992 \\
Cp4-6 & 3 & Cancer pagurus & NE Atlantic & EF031993-EF032001 \\
Co1-2 & 2 & Chionoecetes opilio & Conception Bay, & EF032002-EF032007 \\
& & & Newfoundland & EF032008-EF032010 \\
IvNn1 & 1 & Nephrops norvegicus & Clyde Sea, UK & EF032011-EF032013 \\
IvPb1 & 1 & Pagurus bernhardus & Clyde Sea, UK & \\
\hline
\end{tabular}




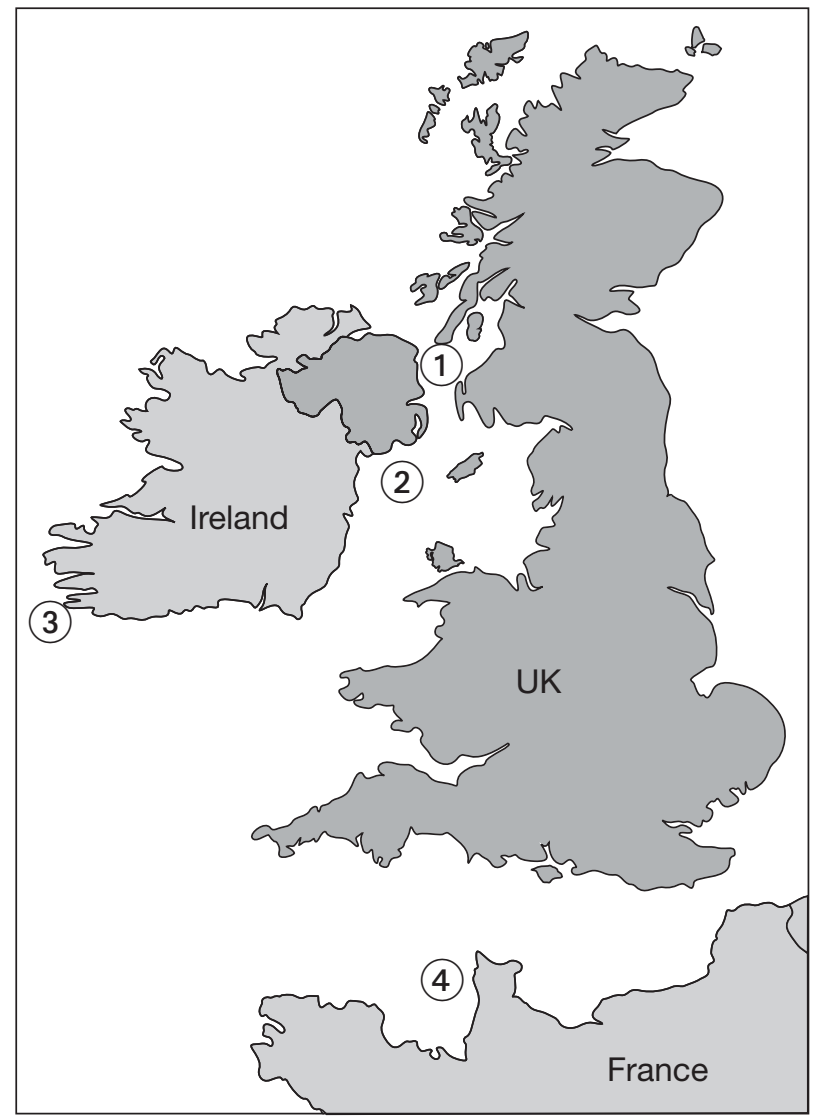

Fig. 1. Hematodinium spp. Locations in UK and Ireland where parasite infected crustaceans were sampled. 1, Clyde Sea area; 2, Irish Sea; 3, northeast Atlantic Ocean; 4, English Channel

Cloning and sequencing. PCR amplification products of approximately $680 \mathrm{bp}$ were excised from agarose gels and purified using a QIA-quick gel extraction kit (Qiagen). Fragments were cloned into the plasmid pCR4-TOPO (Invitrogen) and transformed into E. coli using a TOPO TA Cloning Kit (Invitrogen) following the manufacturer's protocols. Transformed bacterial colonies were screened for inserts using a heat-lysis method and subsequent PCR assay employing the M13 forward and reverse primer pairs supplied in the cloning kit. Briefly, bacterial colonies were picked from the agar plates using a sterile wooden toothpick and then inoculated into $10 \mu \mathrm{l}$ of sterile deionised water. The bacterial cell suspensions were heated for $4 \mathrm{~min}$ at $95^{\circ} \mathrm{C}$ and $0.5 \mu \mathrm{l}$ of the lysis preparation was used as a template in a PCR screen for successful transformation. The amplification reaction mixtures contained $20 \mathrm{mM}$ Tris- $\mathrm{HCl}(\mathrm{pH} 8.4), 50 \mathrm{mM} \mathrm{KCl}$, $1.5 \mathrm{mM} \mathrm{MgCl} 2,0.2 \mathrm{mM}$ dNTPs, each primer at $1.0 \mu \mathrm{M}$, $0.32 \mathrm{U}$ Taq DNA polymerase (Invitrogen), $0.2 \mathrm{mg} \mathrm{ml}^{-1}$ BSA and sterile deionized water to a final volume of $12.5 \mu \mathrm{l}$. Thermocycling conditions were as follows: an initial denaturation at $94^{\circ} \mathrm{C}$ for $2 \mathrm{~min}$, followed by 30 cycles of denaturation at $94^{\circ} \mathrm{C}$ for $30 \mathrm{~s}$, primer annealing at $54^{\circ} \mathrm{C}$ for $30 \mathrm{~s}$ and extension at $72^{\circ} \mathrm{C}$ for $1 \mathrm{~min}$ with the final cycle incorporating a 5 min extension step at $72^{\circ} \mathrm{C}$. Following amplification a $5 \mu \mathrm{l}$ aliquot of each PCR product was electrophoresed on a $2 \%$ $(\mathrm{w} / \mathrm{v})$ agarose gel and visualized as above. PCR products from clones containing the correct insert size were treated with shrimp alkaline phosphatase (SAP) and exonuclease I (Exo I) (Amersham Biosciences) to degrade unincorporated nucleotides and single stranded DNA (primers) remaining after PCR. Five microliters of the M13 PCR product were combined with 0.5 units of SAP and 5.0 units of Exo I and incubated at $37^{\circ} \mathrm{C}$ for $30 \mathrm{~min}, 80^{\circ} \mathrm{C}$ for $15 \mathrm{~min}$ and $15^{\circ} \mathrm{C}$ for $5 \mathrm{~s}$.

Plasmid inserts were sequenced bi-directionally using the Big Dye Terminator kit (Applied Biosystems) with M13 sequencing primers using 1/8th of the recommended Big Dye volume ratio dictated in the manufacturer's protocols. Each $5 \mu \mathrm{l}$ reaction contained $0.0625 \mu \mathrm{l}$ Big Dye, $0.96875 \mu \mathrm{l} 5 \times$ buffer, $1.6 \mathrm{pmol}$ of primer and $10 \mathrm{ng}$ of Exo I/SAP treated PCR product. Thermocycling parameters were as follows: $96^{\circ} \mathrm{C}$ for $1 \mathrm{~min}$, then 25 cycles of $96^{\circ} \mathrm{C}$ for $10 \mathrm{~s}, 50^{\circ} \mathrm{C}$ for $5 \mathrm{~s}, 60^{\circ} \mathrm{C}$ for $4 \mathrm{~min}$ followed by a final incubation at $4^{\circ} \mathrm{C}$. The sequencing reaction products were precipitated using ethanol/sodium acetate (ABI User Bulletin, April 11, 2002). Precipitated sequencing reactions were resuspended in $20 \mu \mathrm{l}$ of $\mathrm{Hi}$-Di formamide (Applied Biosystems) and $10 \mu \mathrm{l}$ of each was electrophoresed on an ABI 3100 or 3130 Prism genetic analyzer (Applied Biosystems). Three DNA clones from each sample were sequenced bidirectionally.

Analysis of sequence data. The Hematodinium rRNA sequences were aligned using the CLUSTAL-W algorithm in the MacVector DNA sequence analysis package (Accelrys) using gap penalties of 8 for insertions and 3 for extensions, in both pairwise and multiple alignment phases, then edited visually. Primer sequences were removed from the $5^{\prime}$ and $3^{\prime}$ end of all sequences generated. To accurately assess sequence variation between samples within the complete ITS1 region the boundaries between the 3 ' end of the 18S rRNA gene, the ITS1 region and the 5 'end of the 5.8S rRNA gene were identified using data from S1 nuclease mapping of Prorocentrum minimum (Maroteaux et al. 1985) and rRNA gene sequence data from Syndinium turbo (Skovgaard et al. 2005). The $3^{\prime}$ end of the 18 S rRNA gene was defined by the sequence 5'-CCT- GCG-GAA-GGA-TCA-TTC-3' and the $5^{\prime}$ end of the 5.8S rRNA gene was defined by $5^{\prime}-$ ATT-TTA-GCG- ATG-AAT-GCC-3'. The partial $18 \mathrm{~S}$ and 5.8S rRNA gene sequences were removed from the alignment. The ITS1 region sequences were aligned with Hematodinium spp. ITS1 sequences in GenBank (DQ084245, DQ084246 and DQ925227 to DQ925236) 
using the same gap penalties (above) and edited visually. MEGA3 (Kumar et al. 2004) was used to calculate pairwise distances (uncorrected genetic distance ' $p$ ' values) between clones and isolate groups (same host species and geographical location).

PCR detection. PCR primers (18S F2 and ITS R1) previously designed to amplify rDNA from the Hematodinium sp. infecting Nephrops norvegicus (Small et al. 2006) were tested to evaluate whether they could be used to detect the Hematodinium spp. present in other crustacean samples. This was done by analysis of the primer binding locations in the 18S rRNA and ITS1 region sequences and testing by means of standard PCR. Amplification reaction mixtures contained $10 \mathrm{mM}$ Tris- $\mathrm{HCl}$ ( $\mathrm{pH}$ 8.3), $50 \mathrm{mM} \mathrm{KCl}, 1 \mathrm{mM} \mathrm{MgCl} 2,0.2 \mathrm{mM}$ dNTPs, each primer at $5.0 \mu \mathrm{M}, 0.4 \mathrm{U}$ Taq DNA polymerase (Invitrogen), 50 to $100 \mathrm{ng}$ DNA template and sterile deionized water to a final volume of $20 \mu$ l. Thermocycling conditions were as follows: an initial denaturation at $94^{\circ} \mathrm{C}$ for 4 min followed by 35 cycles of denaturation at $94^{\circ} \mathrm{C}$ for $30 \mathrm{~s}$, primer annealing at $56^{\circ} \mathrm{C}$ for $30 \mathrm{~s}$, chain extension at $72^{\circ} \mathrm{C}$ for $90 \mathrm{~s}$, with the final cycle incorporating a 5 min extension step at $72^{\circ} \mathrm{C}$. Following amplification a $5 \mu$ l aliquot of each PCR reaction was electrophoresed on a $2 \%$ agarose gel and visualized as above.

\section{RESULTS}

\section{rRNA sequence data}

The expected $\sim 680$ bp 18S-ITS1-5.8S fragments were amplified from all DNA samples. These were cloned, sequenced and deposited in GenBank (see Table 1). The partial $18 \mathrm{~S}$ and $5.8 \mathrm{~S}$ rRNA genes were conserved in all isolates sequenced (4 single nucleotide polymorphisms (SNPs) in the 18S rRNA gene sequences and none in the 5.8S region). Alignment of the sequences generated in this study with partial $18 \mathrm{~S}$ and partial ITS1 region sequences in GenBank for the Hematodinium sp. from Nephrops norvegicus (Accession Nos. DQ084245 and DQ084246) indicated that all sequences obtained originated from Hematodinium and not from the host or other contaminant.

The complete ITS1 region sequences from Hematodinium spp. infecting $\mathrm{Ne}$ phrops norvegicus, Cancer pagurus, Pagurus bernhardus and Chionoecetes opilio were very similar to each other (>98\% similarity) and varied in length between 324 and 345 bp (Table 2). Apart from sequences generated from the in vitro culture from infected $P$. bernhardus, from which all clones had an ITS1 region length of $330 \mathrm{bp}$, the ITS1 region varied even between Hematodinium samples from the same location and crustacean host. The sequence alignment revealed the presence of 4 different microsatellites responsible for the length variation of the ITS1 region (Table 3). The insertion of an adenine at the $72 \mathrm{bp}$ position of the ITS1 alignment was observed in all clone sequences from the $P$. bernhardus isolate only and led to the extension $(\mathrm{n}=3)$ of a tetranucleotide microsatellite motif. In multiple instances clone sequences generated from the same sample showed variation in the number of microsatellites. For example, the Hematodinium ITS1 region from the second infected $N$. norvegicus sample from the Clyde Sea area (Nn2) had a TG motif (at $103 \mathrm{bp}$ of the alignment) repeated 11,12 and 13 times, respectively, in the 3 clones sequenced. Eighteen different SNPs (at different locations) were detected between the 48 ITS1

Table 2. Hematodinium spp. Size of partial 18S rRNA gene, complete ITS1 region, and partial 5.8S rRNA gene region for the organism studied

\begin{tabular}{|lccc|}
\hline $\begin{array}{l}\text { Hematodinium spp. } \\
\text { from host (no. of clones) }\end{array}$ & $\begin{array}{c}\text { Partial 18S } \\
\text { (bp) }\end{array}$ & $\begin{array}{c}\text { ITS1 } \\
\text { (bp) }\end{array}$ & $\begin{array}{c}\text { Partial 5.8S } \\
\text { (bp) }\end{array}$ \\
\hline Nephrops norvegicus (18) & 217 & $336-345$ & 35 \\
Cancer pagurus (18) & 217 & $329-333$ & 35 \\
Chionoecetes opilio (6) & 217 & $324-333$ & 35 \\
Nephrops norvegicus in vitro culture (3) & 217 & $339-345$ & 35 \\
Pagurus bernhardus in vitro culture (3) & 217 & 330 & 35 \\
\hline
\end{tabular}

Table 3. Hematodinium spp. ITS1 region microsatellites responsible for length variation. See Table 1 for sample sources

\begin{tabular}{|c|c|c|c|c|}
\hline \multirow{2}{*}{ Sample } & \multirow[b]{2}{*}{$\begin{array}{c}66 \\
(\mathrm{CATG})_{\mathrm{n}}\end{array}$} & \multicolumn{2}{|c|}{ ITS1 region alignment position } & \multirow{2}{*}{ n $\frac{294}{(\mathrm{GAA})_{\mathrm{n}}(\mathrm{GGA})_{\mathrm{n}}}$} \\
\hline & & $\begin{array}{c}83 \\
(\mathrm{GCC})_{\mathrm{n}} \mathrm{TCCGC}(\mathrm{TG})_{\mathrm{n}}\end{array}$ & $\begin{array}{l}254 \\
(\mathrm{TA})_{\mathrm{n}}\end{array}$ & \\
\hline Nn1 & $(\mathrm{CATG})_{1}$ & $(\mathrm{GCC})_{3} \mathrm{TCCGC}(\mathrm{TG})_{8-9}$ & $(\mathrm{TA})_{2}$ & $(\mathrm{GAA})_{4-5}(\mathrm{GGA})_{6}$ \\
\hline Nn2 & $(\mathrm{CATG})_{1}$ & $(\mathrm{GCC})_{3} \mathrm{TCCGC}(\mathrm{TG})_{11-13}$ & $(\mathrm{TA})_{2}$ & $(\mathrm{GAA})_{4}(\mathrm{GGA})_{5-6}$ \\
\hline Nn3 & $(\mathrm{CATG})_{1}$ & $(\mathrm{GCC})_{3-5} \mathrm{TCCGC}(\mathrm{TG})_{8-9}$ & $(\mathrm{TA})_{2}$ & $(\mathrm{GAA})_{4-5}(\mathrm{GGA})_{5-6}$ \\
\hline Nn4 & $(\mathrm{CATG})_{1}$ & $(\mathrm{GCC})_{3-5} \mathrm{TCCGC}(\mathrm{TG})_{8}$ & $(\mathrm{TA})_{2}$ & $(\mathrm{GAA})_{4-5}(\mathrm{GGA})_{6}$ \\
\hline Nn5 & $(\mathrm{CATG})_{1}$ & $(\mathrm{GCC})_{3} \mathrm{TCCGC}(\mathrm{TG})_{8-9}$ & $(\mathrm{TA})_{2}$ & $(\mathrm{GAA})_{4-5}(\mathrm{GGA})_{5-6}$ \\
\hline Nn6 & $(\mathrm{CATG})_{1}$ & $(\mathrm{GCC})_{5} \mathrm{TCCGC}(\mathrm{TG})_{9}$ & $(\mathrm{TA})_{2}$ & $(\mathrm{GAA})_{4}(\mathrm{GGA})_{6}$ \\
\hline Cp1 & $(\mathrm{CATG})_{1}$ & $(\mathrm{GCC})_{3} \mathrm{TCCGC}(\mathrm{TG})_{8-9}$ & $(\mathrm{TA})_{2}$ & $(\mathrm{GAA})_{3}(\mathrm{GGA})_{5}$ \\
\hline Cp2 & $(\mathrm{CATG})_{1}$ & $(\mathrm{GCC})_{3} \mathrm{TCCGC}(\mathrm{TG})_{9}$ & $(\mathrm{TA})_{2}$ & $(\mathrm{GAA})_{3}(\mathrm{GGA})_{5}$ \\
\hline Cp3 & $(\mathrm{CATG})_{1}$ & $(\mathrm{GCC})_{3} \mathrm{TCCGC}(\mathrm{TG})_{8-9}$ & $(\mathrm{TA})_{2}$ & $(\mathrm{GAA})_{3}(\mathrm{GGA})_{5}$ \\
\hline Cp4 & $(\mathrm{CATG})_{1}$ & $(\mathrm{GCC})_{3} \mathrm{TCCGC}(\mathrm{TG})_{7-9}$ & $(\mathrm{TA})_{2}$ & $(\mathrm{GAA})_{3}(\mathrm{GGA})_{5}$ \\
\hline Cp5 & $(\mathrm{CATG})_{1}$ & $(\mathrm{GCC})_{3} \mathrm{TCCGC}(\mathrm{TG})_{7-9}$ & $(\mathrm{TA})_{2}$ & $(\mathrm{GAA})_{3}(\mathrm{GGA})_{5}$ \\
\hline Cp6 & $(\mathrm{CATG})_{1}$ & $(\mathrm{GCC})_{3} \mathrm{TCCGC}(\mathrm{TG})_{7-9}$ & $(\mathrm{TA})_{2}$ & $(\mathrm{GAA})_{3}(\mathrm{GGA})_{5}$ \\
\hline Co1 & $(\mathrm{CATG})_{1}$ & $(\mathrm{GCC})_{3} \mathrm{TCCGC}(\mathrm{TG})_{5-6}$ & $(\mathrm{TA})_{2-3}$ & $(\mathrm{GAA})_{3-4}(\mathrm{GGA})_{4-6}$ \\
\hline Co2 & $(\mathrm{CATG})_{1}$ & $(\mathrm{GCC})_{3} \mathrm{TCCGC}(\mathrm{TG})_{6}$ & $(\mathrm{TA})_{3}$ & $(\mathrm{GAA})_{3-4}(\mathrm{GGA})_{5}$ \\
\hline IvNn1 & $(\mathrm{CATG})_{1}$ & $(\mathrm{GCC})_{3-5} \mathrm{TCCGC}(\mathrm{TG})_{9}$ & $(\mathrm{TA})_{2}$ & $(\mathrm{GAA})_{4}(\mathrm{GGA})_{6}$ \\
\hline IvPb1 & $(\mathrm{CATG})_{3}$ & $(\mathrm{GCC})_{3} \mathrm{TCCGC}(\mathrm{TG})_{6}$ & $(\mathrm{TA})_{3}$ & $(\mathrm{GAA})_{3}(\mathrm{GGA})_{5}$ \\
\hline
\end{tabular}


clone sequences analyzed, with approximately $90 \%$ of these being polymorphism transitions and $10 \%$ transversions. Generally, the polymorphisms were distributed evenly throughout the different ITS1 clones such that each sequence differed from the others by 1 or $2 \mathrm{bp}$.

ITS1 region sequences from the same group (same host species and geographical location) ranged from 98.6 to $99.7 \%$ similarity (Table 4 ). Identical ITS1 region sequences were found in multiple DNA clones from many isolates. The ITS1 region sequences from the Hematodinium spp. from Nephrops norvegicus, Cancer pagurus, and Pagurus bernhardus showed 99.0 to $100 \%$ similarity to each other, while the ITS1 region sequences from the Hematodinium sp. from Chionoecetes opilio showed $>98 \%$ similarity to the other Hematodinium spp. sequences from UK crustacean hosts. All ITS1 region sequences from the Hematodinium sp. from Callinectes sapidus were 68.7 to $71.0 \%$ similar to the Hematodinium spp. sequences from the other crustacean hosts.

\section{PCR detection}

Analysis of the primer binding sites (18S F2 and ITS R1, Small et al. 2006a) in the Hematodinium spp. 18S rRNA gene and ITS1 region sequences revealed the conserved nature of the primer target regions in the Hematodinium sequences. Of the 48 sequences generated in this study there was 1 single base pair mismatch at the forward primer binding site (80 to $102 \mathrm{bp}$ upstream of the 18S/ITS1 boundary) in one 18S rRNA gene sequence. This was caused by a transition at the 5th nucleotide position of the forward primer sequence. Analysis of the ITS1 region sequence alignment revealed one mismatch in the reverse primer binding region (256 to $277 \mathrm{bp}$ downstream of the 18S/ITS1 boundary) in 1 clone sequence, caused by a transition at the 5th nucleotide position in the primer binding site.

Amplification of DNA samples extracted from infected Nephrops norvegicus from the Clyde and Irish seas using the primer pair 18S F2 and ITS R1 produced a single reaction product of $\sim 380 \mathrm{bp}$. The primers also amplified the 380 bp diagnostic Hematodinium DNA fragment from infected Cancer pagurus from the English Channel and Atlantic Ocean from the in vitro Hematodinium spp. cultures isolated from infected Pagurus bernhardus and $N$. norvegicus and from infected Chionoecetes opilio from Conception Bay, on the island of Newfoundland (Table 5). The PCR primer pair did not generate any PCR product when tested against genomic DNA preparations from Hematodinium spp. infecting blue crabs, harbour crabs, or sand crabs Portunus trituberculatus (Table 5).

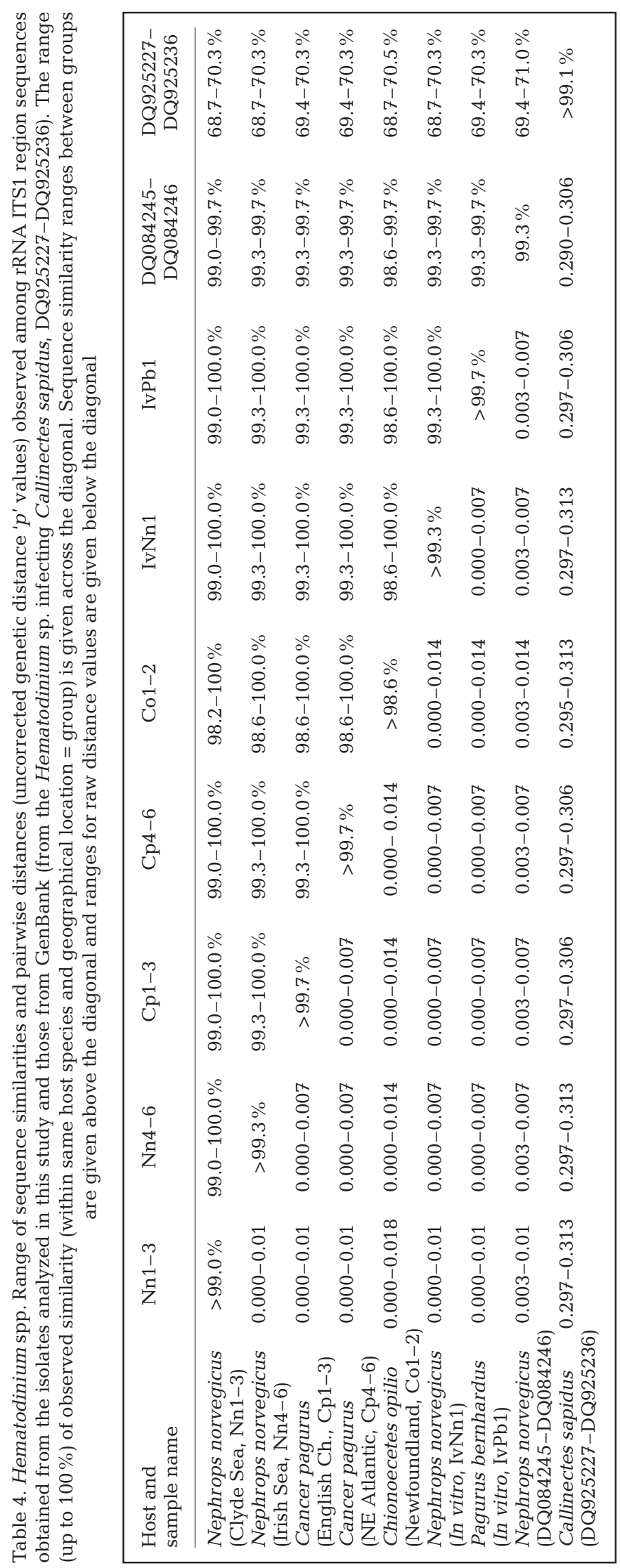


Table 5. Hematodinium spp. Specificity of a previously developed PCR assay (Small et al. 2006) to detect parasitic infection in other crustacean hosts

\begin{tabular}{|lc|}
\hline Hematodinium infected host samples & $\begin{array}{c}\text { PCR } \\
\text { diagnosis }\end{array}$ \\
\hline Nephrops norvegicus - Clyde Sea Area, UK $(\mathrm{n}=6)$, Irish Sea, UK $(\mathrm{n}=8)$ & + \\
Cancer pagurus - English Channel, UK $(\mathrm{n}=4), 6$ Atlantic Ocean $(\mathrm{n}=6)$ & + \\
Pagurus bernhardus - Clyde Sea, UK $(\mathrm{n}=1)$ & + \\
Chionoecetes opilio - Conception Bay, Newfoundland, Canada $(\mathrm{n}=6)$ & + \\
Liocarcinus depurator - English Channel, UK $(\mathrm{n}=4)$ & - \\
Callinectes sapidus - Virginia, USA (n $=6)$ & - \\
Portunus trituberculatus - Zhejiang Province, China $(\mathrm{n}=3)$ & - \\
\hline
\end{tabular}

\section{DISCUSSION}

This study represents the first detailed analysis of the complete ITS1 rRNA region of Hematodinium spp. infecting several host species (Nephrops norvegicus, Cancer pagurus, Chionoecetes opilio and Pagurus bernhardus) from different geographic locations. Sequence analysis revealed that the ITS1 region from the Hematodinium species infecting $N$. norvegicus, C. pagurus, $P$. bernhardus and C. opilio were very similar; therefore, we suggest that these hosts are infected with the same species of parasite. Four microsatellites were found within the ITS1 region and account for the length variation observed. In addition, the primers previously designed by Small et al. (2006) to detect Hematodinium infections in $N$. norvegicus also detected the parasite infecting C. pagurus and C. opilio and amplified the DNA isolated from an in vitro culture of Hematodinium sp. from $P$. bernhardus. Consequently, this PCR-based diagnostic assay could be used to screen these crustacean species for the parasite.

Molecular sequence information has been used to supplement the morphological taxonomy of many marine parasites. Examples include the phylogenetic position of Marteilia refringens (Berthe et al. 2000), Pfiesteria shumwayae (Litaker et al. 2005), and the phylogenetic synonymization of Perkinsus chesapeaki and $P$. andrewsi (Burreson et al. 2005). Ribosomal DNA sequence variation has previously been used to discriminate between toxic and non-toxic strains of Alexandrium tamarense and Pseudonitzschia spp. (Scholin et al. 1994, Higman et al. 2001) and the geographic origin and identity of virulent Perkinsus marinus strains (Robledo et al. 1999, Reece et al. 2001). A PCR-based restriction fragment length polymorphism assay (PCR-RFLP) based on the ITS1 region has been used to differentiate between Hematodinium infections in Callinectes sapidus, Liocarcinus depurator and Portunus trituberculatus (Small et al. 2007) suggesting that this region can be used to identify different Hematodinium species. The use of the ITS1 region to differentiate be- tween Hematodinium spp. is further supported by the large genetic distances observed in this study between the Hematodinium sp. from C. sapidus compared with Hematodinium spp. from Nephrops norvegicus, Cancer pagurus and Chionoecetes opilio (Table 4).

In this study 18 single nucleotide polymorphisms were found in the ITS1 region. The number of nucleotide substitutions (independent of microsatellites), $0.33 \times 10^{-2}$ to $1.25 \times$ $10^{-2}$ per $\mathrm{bp}$, is larger than the reported Taq polymerase error rate $\left(1.1 \times 10^{-4}\right)$ (Tindall \& Kunkel 1988). This is most likely due to the amplification and sequencing of different ITS1 region repeat motifs, as each SNP was only observed in single clone sequences similar to the observed SNPs in the ITS1 region from the Hematodinium sp. infecting Callinectes sapidus (Small et al. 2007). Based on the ITS1 region data, it appears that Nephrops norvegicus, Cancer pagurus, Chionoecetes opilio and Pagurus bernhardus are all infected with the same species of Hematodinium, this indicates that this parasite species is a host generalist with a broad geographic range.

Significant length variation in the ITS1 region (due to microsatellites) was observed in the clone sequences from all Hematodinium spp. ITS1 region sequences generated in this study. This is, therefore, the first report of microsatellites in Hematodinium spp. These short sequence repeats are extremely abundant in eukaryotic genomes and are believed to arise through 'slippage' events during DNA replication (Levinson \& Gutman 1987, Pupko \& Graur 1999). Microsatellites in the ITS regions have been found in other parasitic taxa including Schistosoma (Van Herwerden et al. 1998), Trypanosoma (Beltrame-Botelho et al. 2005) and Metastrongylus (Conole et al. 2001). In this study the ITS1 sequences from each isolate were examined by PCR amplification and sequencing of 3 clones. Apart from the Pagurus bernhardus isolate, in which all 3 clone sequences were the same length, the majority of the other isolates had different numbers of repeats between the 3 clones from the same sample. This may be due to infection of the crustacean host with multiple strains of Hematodinium with variable repeat numbers or due to variable ITS1 repeats within the genome of the parasite, as has been observed in similar organisms (Litaker et al. 2003, Brown et al. 2004). All of the ITS1 region sequences from the Hematodinium sp. from Cancer pagurus had fewer repeats of 2 microsatellites $\left([G C C]_{n}\right.$ and $\left.[G A A]_{n}[G G A]_{n}\right)$ when compared with those from the Hematodinium sp. from Nephrops norvegicus. Although the sample size was low the 
reduced genetic diversity may indicate that a founder event occurred and that this Hematodinium sp. was introduced to C. pagurus from $N$. norvegicus, as both host species can be found in the same area. The generation and genetic analysis of clonal cultures of Hematodinium or the genetic analysis of single parasite cells is required to investigate the sequence and length variability of this region.

Morphologically, the Hematodinium species from Nephrops norvegicus and Cancer pagurus from the Clyde Sea and English Channel, respectively, are similar and present in both hosts as uni-, bi- and multinucleate forms of comparable size. Parasite cells have similar condensed chromatin profiles, lipid droplets, trichocysts, mitochondria and other organelles (Field et al. 1992, Stentiford et al. 2002). The pathology of infection is similar in both hosts with several tissues being infiltrated by large numbers of parasites (Field \& Appleton 1995), however, a subtle difference exists in the pathologies of infection. The claw muscle of $N$. norvegicus is heavily infiltrated by the parasite but the Z-lines of the sarcomeres remain intact (Stentiford et al. 2000). In contrast, the sarcomeres from claw muscle fibres of infected C. pagurus are severely disorganised in the region of the Z-line (Stentiford et al. 2002). Given these infections are presumed to be caused by the same species of Hematodinium the above differences in pathology may indicate a difference in parasite virulence or host susceptibility and warrants further study.

The Hematodinium specific primer set developed to detect the Hematodinium sp. infecting Nephrops norvegicus from the Clyde Sea area in Scotland (Small et al. 2006) binds to the rRNA gene sequences of the Hematodinium spp. isolates infecting $N$. norvegicus from the Irish Sea, Cancer pagurus from the English Channel and Atlantic Ocean, Pagurus bernhardus from the Clyde Sea, and Chionoecetes opilio from Conception Bay, Newfoundland. This observation was confirmed by performing the PCR assay on DNA samples from these host crustaceans with known infections. The successful amplification of Hematodinium rDNA from these samples illustrates that this assay may be used to screen these host species for the parasite. Small et al. (2006) also designed 2 in situ DNA probes (using the DIG detection system) for Hematodinium spp., the first binding to both the $3^{\prime}$ end of the 18S rRNA gene and the ITS1 region (probe 1) while the second bound only to the $3^{\prime}$ end of the 18S rRNA gene (probe 2). The authors noted that the in situ signal from probe 1 was weaker than probe 2 and attributed this to the increased length of probe 1 versus probe 2 and also that the ITS region is unstable after being excised from the final rRNA product. The results from this study, however, indicate that the microsatellite variation discovered within the ITS1 region repeats may also contribute to a reduction in probe binding efficiency. Consequently, probe 1 would not have the highest binding capacity when compared with the conserved 18S rRNA gene sequence that probe 2 was based upon.

In summary, ITS1 region sequences from Hematodinium spp. infecting Nephrops norvegicus, Cancer pagurus, Pagurus bernhardus and Chionoecetes opilio suggest that these hosts are all infected with the same species of Hematodinium. This is an intriguing finding because large distances separate the ranges of the Norway lobster, edible crab and snow crab hosts. Four microsatellites are responsible for length variation in the ITS1 region in this species of Hematodinium and these microsatellites may be indicative of different strains of this parasite species. Finally, the conserved domains in the $18 \mathrm{~S}$ and ITS1 region (previously targeted in a PCR assay, Small et al. 2006) allow the use of this PCR-based assay for the rapid detection of this Hematodinium species in N. norvegicus, Cancer pagurus, $P$. bernhardus and Chionoecetes opilio.

Acknowledgements. We thank G. Stentiford (Centre for Environment, Fisheries \& Aquaculture Science, Weymouth, UK), R. Briggs (Department of Agriculture \& Rural Development, Northern Ireland), M. Robinson (Galway Mayo Institute of Technology), D. Taylor (Fisheries \& Oceans, Canada), W. Xu (Marine Fisheries Research Institute of Zhejiang) and J. Atkinson and K. Vickerman (University of Glasgow) for their help in obtaining samples of Hematodinium infected hosts. We also thank Dr. Gwynne Brown for her critique of the manuscript. This is VIMS contribution 2804.

\section{LITERATURE CITED}

Anonymous (2004) Report of the study group on the biology and life history of crabs. ICES CM 2004/G:13

Beltrame-Botelho IT, Gaspar-Silva D, Steindel M, Davila AM, Grisard EC (2005) Internal transcribed spacers (ITS) of Trypanosoma rangeli ribosomal DNA (rDNA): a useful marker for inter-specific differentiation. Inf Gen Evol 5:17-28

Berthe FCJ, Le Roux F, Peyretaillade E, Peyret P, Rodriguez D, Gouy M, Vivarès CP (2000) Phylogenetic analysis of the small subunit ribosomal RNA of Marteilia refringens validates the existence of Phylum Paramyxea (Desportes and Perkins, 1990). J Eukaryot Microbiol 47:288-293

Bower SM, Meyer GM, Phillips A, Workman G, Clark D (2003) New host and range extension of bitter crab syndrome in Chionoecetes spp. caused by Hematodinium sp. Bull Euro Assoc Fish Pathol 23:86-91

Briggs RP, McAliskey M (2002) The prevalence of Hematodinium in Nephrops norvegicus from the Western Irish Sea. J Mar Biol Assoc UK 82:427-433

Brown G, Hudson KL, Reece KS (2004) Genetic variation at the ITS and ATAN loci among and within cultured isolates of Perkinsus marinus. J Eukaryot Microbiol 51:312-320

Burreson EM, Dungan CF, Reece KS (2005) Molecular, morphological, and experimental evidence support the synonymy of Perkinsus chesapeaki and Perkinsus andrewsi. J Eukaryot Microbiol 52:258-270

Chatton É, Poisson R (1931) Sur l'existence, dans le sand des Crabes, de Péridinien parasites: Hematodinium perezi n. g., 
n. sp. (Syndinidae). CR Seances Soc Biol Paris 105:553-557

Conole JC, Chilton NB, Jarvis T, Gasser RB (2001) Mutation scanning analysis of microsatellite variability in the second internal transcribed spacer (precursor ribosomal RNA) for 3 species of Metastrongylus (Strongylida: Metastrongyloidea). Parasitology 122:195-206

Felleisen RSJ (1997) Comparative sequence analysis of 5.8S rRNA genes and internal transcribed spacer (ITS) regions of trichomonadid protozoa. Parasitology 115:111-119

Field RH, Appleton PL (1995) A Hematodinium-like dinoflagellate infection of the Norway lobster Nephrops norvegicus: observations on pathology and progression of infection. Dis Aquat Org 22:115-128

Field RH, Chapman CJ, Taylor AC, Neil DM, Vickerman K (1992) Infection of the Norway lobster Nephrops norvegicus by a Hematodinium-like species of dinoflagellate on the west coast of Scotland. Dis Aquat Org 13:1-15

Field RH, Hills JM, Atkinson RJA, Magill S, Shanks AM (1998) Distribution and seasonal prevalence of Hematodinium sp. infection of the Norway lobster (Nephrops norvegicus) around the west coast of Scotland. ICES J Mar Sci 55: 846-858

Goggin CL (1994) Variation in the two internal transcribed spacers and 5.8S ribosomal RNA from five isolates of the marine parasite Perkinsus (Protista, Apicomplexa). Mol Biochem Parasitol 65:179-182

Gruebl T, Frischer ME, Sheppard M, Neumann M, Maurer AN, Lee RF (2002) Development of an 18S rRNA gene-targeted PCR-based diagnostic for the blue crab parasite Hematodinium sp. Dis Aquat Org 49:61-70

Higman WA, Stone DM, Lewis JM (2001) Sequence comparisons of toxic and non-toxic Alexandrium tamarense (Dinophyceae) isolates from UK waters. Phycologia 40:256-262

Hudson DA, Adlard RD (1994) PCR techniques applied to Hematodinium spp. and Hematodinium-like dinoflagellates in decapod crustaceans. Dis Aquat Org 20:203-206

Hudson DA, Adlard RD (1996) Nucleotide sequence determination of the partial SSU rDNA gene and ITS1 region of Hematodinium cf. perezi and Hematodinium-like dinoflagellates. Dis Aquat Org 24:55-60

Hudson DA, Shields JD (1994) Hematodinium australis n. sp., a parasitic dinoflagellate of the sand crab Portunus pelagicus from Moreton Bay, Australia. Dis Aquat Org 19:109-119

Kumar S, Tamura K, Nei M (2004) MEGA3: Integrated software for molecular evolutionary genetics analysis and sequence alignment. Brief Bioinform 5:150-163

Latrouite D, Morizur T, Noel P, Chagot D, Wilhelm G (1988) Mortalite du tourteau Cancer pagurus provoquee par le dinoflagellate parasite: Hematodinium sp. ICES CM 1988/K:32

Levinson G, Gutman GA (1987) Slipped-strand mispairing: a major mechanism for DNA sequence evolution. Mol Biol Evol 4:203-221

Litaker RW, Vandersea MW, Kibler SR, Reece KS and 6 others (2003) Identification of Pfiesteria piscicida (Dinophyceae) and Pfiesteria-like organisms using internal transcribed spacer-specific assays. J Phycol 39:754-761

Litaker RW, Steidinger KA, Mason PL, Lansberg JH and 7 others(2005) The reclassification of Pfiesteria shumwayae (Dinophyceae): Pseudopfiesteria, gen. nov. J Phycol 41: 643-651

Long EO, Dawid IB (1980) Repeated genes in eukaryotes. Annu Rev Biochem 49:727-764

Maroteaux L, Herzog M, Soyer-Gobillard MO (1985) Molecular organization of dinoflagellate ribosomal DNA: evolutionary implications of the deduced 5.8S rRNA secondary structure. Biosystems 18:307-319

Meyers TR, Koeneman TM, Botelho C, Short S (1987) Bitter crab disease: a fatal dinoflagellate infection and marketing problem for Alaskan Tanner crabs Chionoecetes bairdi. Dis Aquat Org 3:195-216

Newman MW, Johnson CA (1975) A disease of blue crabs (Callinectes sapidus) caused by a parasitic dinoflagellate, Hematodinium sp. J Parasitol 63:554-557

Pupko T, Graur D (1999) Evolution of microsatellites in the yeast Saccharomyces cerevisiae: role of length and number of repeated units. J Mol Evol 48:313-316

Reece KS, Bushek D, Graves JE (1997) Molecular markers for population genetic analysis of Perkinsus marinus. Mol Mar Biol Biotechnol 6:197-206

Reece KS, Bushek D, Hudson KL, Graves JE (2001) Geographical distribution of Perkinsus marinus genetic strains along the Atlantic and Gulf coasts of the USA. Mar Biol 139: 1047-1055

Robledo JAF, Wright AC, Marsh AG, Vasta GR (1999) Nucleotide sequence variability in the nontranscribed spacer of the rRNA locus in the oyster parasite Perkinsus marinus. J Parasitol 85:650-656

Scholin CA, Villac MC, Buck KR, Krupp JM, Powers DA, Fryxell GA, Chavez FP (1994) Ribosomal DNA sequences discriminate among toxic and non-toxic Pseudonitzschia species. Natural Toxins 2:152-165

Skovgaard A, Massana R, Balague V, Saiz E (2005) Phylogenetic position of the copepod-infesting parasite Syndinium turbo (Dinoflagellata, Syndinea). Protist 156:413-423

Small HJ, Neil DM, Taylor AC, Atkinson RJA, Coombs GH (2006) Molecular detection of Hematodinium spp. in Norway lobster Nephrops norvegicus and other crustaceans. Dis Aquat Org 69:185-195

Small HJ, Shields JD, Hudson KL, Reece KS (2007) Molecular detection of the Hematodinium sp. infecting the blue crab, Callinectes sapidus. J Shellfish Res 26:1-9

Som I, Azam A, Bhattacharya A, Bhattacharya S (2000) Interand intra-strain variation in the 5.8S ribosomal RNA and internal transcribed spacer sequences of Entamoeba histolytica and comparison with Entamoeba dispar, Entamoeba moshkovskii and Entamoeba invadens. Int J Parasitol 30:723-728

Stentiford GD, Shields JD (2005) A review of the parasitic dinoflagellates Hematodinium species and Hematodiniumlike infections in marine crustaceans. Dis Aquat Org 66: $47-70$

Stentiford GD, Neil DM, Coombs GH (2000) Alterations in the biochemistry and ultrastructure of the deep abdominal flexor muscle of the Norway lobster Nephrops norvegicus during infection by a parasitic dinoflagellate of the genus Hematodinium. Dis Aquat Org 42:133-141

Stentiford GD, Green M, Bateman K, Small HJ, Neil DM, Feist SW (2002) Infection by a Hematodinium-like parasitic dinoflagellate causes Pink Crab Disease (PCD) in the edible crab Cancer pagurus. J Inv Pathol 79:179-191

Taylor DM, Khan RA (1995) Observations on the occurrence of Hematodinium sp. (Dinoflagellata: Syndinidae), the causative agent of bitter crab disease in Newfoundland snow crab (Chionoecetes opilio). J Invertebr Pathol 65: $283-288$

Tindall KR, Kunkel TA (1988) Fidelity of DNA synthesis by the Thermus aquaticus DNA polymerase. Biochemistry 27: 6008-6013

Van Herwerden L, Blair D, Agatsuma T (1998) Intra- and interspecific variation in the nuclear ribosomal internal transcribed spacer 1 of the Schistosoma japonicum species complex. Parasitology 116:311-317

Wilhelm G, Mialhe E (1996) Dinoflagellate infection associated with the decline of Necora puber crab populations in France. Dis Aquat Org 26:213-219 